\title{
Kontroversi Produk Rekayasa Genetika Yang Dikonsumsi Masyarakat
}

\author{
Oleh: Mahrus \\ Program Studi Pendidikan Biologi
}

\begin{abstract}
ABSTRAK
Rekayasa genetika adalah transplantasi satu gen ke gen lainnya baik antara gen dan lintas gen untuk menghasilkan produk yang berguna bagi mahluk hidup hidup. Pada awalnya, rekayasa genetika hanya dilakukan pada tanaman untuk memecahkan kekurangan pangan penduduk dunia, dan dalam pengembangannya rekayasa genetika tidak hanya berlaku untuk tanaman dan hewan yang serupa, tetapi telah berevolusi pada manusia dan lintas jenis. Prinsip dasar teknologi rekayasa genetika adalah memanipulasi perubahan komposisi asam nukleat DNA atau menyelipkan gen baru ke dalam struktur DNA mahluk hidup penerima, hal ini berarti bahwa gen yang disisipkan pada mahluk hidup penerima dapat berasal dari mahluk hidup lain. Saat ini, penyebaran dan penggunaan produk rekayasa genetika telah mengundang kontroversi masyarakat, oleh karena itu tulisan ini bertujuan untuk meninjau kontroversi rekayasa genetika mahluk hidup pada beberapa aspek kehidupan masyarakat.
\end{abstract}

Kata Kunci: gekayasa genetika, gen, DNA, GMO, kontroversi.

\section{CONTROVERSY OF GENETIC ENGINEERING PRODUCT CONSUMED SOCIETY}

\begin{abstract}
Genetic engineering is a transplant of one gene to an other gene both between genes and gene cross to produce a useful product for living organisms. At first, genetic engineering was only conducted on plant to solve the food's lack for world population, and it does not only apply to the plants and animals are similar in its development, but it has evolved in humans and cross types. The basic principle of genetic engineering technology is manipulating the composition changes of the nucleic acid of DNA or tucking new genes into the DNA structure of the recipient organisms, this means that inserted genes on a recipient organism can be derived from the other organisms. Today, the deployment and use of genetically modified organisms have been inviting society's controversy, therefore this paper aims to review the controversy for genetically modified organism (GMO) on several aspects of community life.
\end{abstract}

Keywords: genetic engineering, gene, DNA, GMO, controversy.

\section{PENDAHULUAN}

$\mathrm{P}$ erkembangan ilmu pengetahuan dan teknologi rekayasa genetika (genetic engineering) akhir-akhir ini cukup drastis dan meminta perhatian serius dari pemerintah dan para ilmuwan (Dresbach et al., 2001; Curran and Koszarycz, 2004; Small et al., 2005; Dano, 2007; Amin et al., 2010). Rekayasa genetika pada dasarnya adalah seperangkat teknik yang digunakan untuk memanipulasi komponen genetik, yakni DNA genom atau gen yang dapat dilakukan dalam satu sel atau mahluk hidup (organisme), bahkan dari satu mahluk hidup ke mahluk hidup lain yang berbeda jenisnya (Uzogara, 2000; Small, 
2004; Montaldo, 2006; Alberts et al., 2008; Sudjadi, 2008; Artanti et al., 2010; Asaye et al., 2014; Pramashinta et al., 2014). Mahluk hidup yang materi genetiknya telah dimanipulasi secara artifisial di laboratorium melalui rekayasa genetika disebut dengan mahluk hidup transgenic atau rekayasa genetika mahluk hidup (genetically modified organism/GMO) yang memiliki sifat unggul dibandingkan dengan mahluk hidup asalnya (Lotter, 2008; Marinho et al., 2012).

Tujuan utama pengembangan GMO adalah untuk mengatasi berbagai masalah kekurangan pangan yang dihadapi penduduk dunia yang tidak mampu dipecahkan secara konvensional, karena pertumbuhan penduduk yang begitu cepat (Amin et al., 2010; Azadi dan Peter, 2010; Artanti et al., 2010; Marinho et al., 2012; Pramashinta et al., 2014). Namun dalam pengembangannya sampai saat ini, GMO masih menimbulkan pro kontra (kontroversi) di tengah-tengah masyarakat dunia, baik yang terjadi di negara dimana GMO dikembangkan maupun di negaranegara pengguna produk GMO. Kontroversi yang sangat tajam justru terjadi di kalangan para ilmuwan, masingmasing kelompok bertahan pada alasan yang dapat diterima secara ilmiah (Dano, 2007; Sutardi, 2007; Abbas, 2009; Amin et al., 2010; Burachik, 2010; Pramashinta et al., 2014).

Kelompok yang pro GMO beralasan bahwa ada potensi tak terbatas dalam rekayasa genetika yang bermanfaat untuk mengurangi penggunaan pestisida, mengatasi kekurangan pangan, dan menghasilkan makan-makanan yang lebih bergizi serta obat-obatan. Kelompok yang kontra/menolak berpendapat produk pangan dan obat-obatan GMO belum diyakini aman untuk dikonsumsi karena masih menimbulkan berbagai dampak negatif bagi kesehatan dan lingkungan.
Dampk negatif lainnya bagi para petani khususnya adalah sangat merugikan mereka, karena petani non GMO tidak mampu meningkatkan produktifitas yang lebih menguntungkan (Hardinsyah, 2000). Semua dampak negatif tersebut sampai saat ini kurang mendapat perhatian pemerintah dan ilmuwan seperti yang dilaporkan oleh Dano (2007).

Argentina adalah negara terbesar kedua di dunia yang mengembangkan tanaman GMO yang didukung oleh empat faktor utama, yaitu (Burachik (2010): dukungan politik; kemampuan untuk memecahkan kebutuhan petani; faktor ekonomi dan lingkungan; dan implementasi peraturan perundangundangan yang berlaku. Produk pangan dalam negeri yang ada saat ini belum mampu mengatasi masalah kekurangan pangan, dan hal ini menjadi tantangan pembanguan pertanian di Indonesia (Nursamsi, 2008). Meskipun Indonesia telah berhasil memproduksi GMO sejak tahun 1999, Indonesia masih saja mengimpor terus menerus 10 bahan pokok dari berbagai negara yang diduga hasil rekayasa genetika yaitu: beras, jagung, kedelai, biji gandum, tepung terigu, gula pasir, daging sapi, daging ayam, garam, singkong, dan kentang (BPS, 2013). Produk lainnya seperti buah-buahan impor di supermarket merupakan produk GMO, namun sayangnya semua produk GMO yang beredar di pasaran tidak diberi informasi yang jelas, oleh karena itu permasalahan yang paling menonjol dan masih menimbulkan kontroversi di masyarakat adalah amankah produk GMO yang menguasai pasar saat ini utuk dikonsumsi?.

Tulisan ini bertujuan untuk membahas masalah kontroversi penerimaan dan penggunaan produk GMO pada 6 aspek kehidupan masyarakat yaitu: pertanian, lingkungan, kesehatan, agama, budaya, 
dan etika. Untuk mengkaji permasalahan ini, penulis mencoba membandingkan keuntungan dan kerugian dari produk GMO, dan kemudian mengidentifikasi dampak positif dan negatifnya secara jelas dengan referensi yang ada pada negaranegara maju dan berkembang. Diharapkan dari tulisan ini, kontroversi yang berkembang di tengah-tengah kehidupan masyarakat dapat ditiadakan atau paling tidak dapat diminimalkan.

\section{METODE REKAYASA GENETIKA}

Beberapa istilah yang digunakan pada rekayasa genetika adalah: transgenik; modifikasi genetika (genetically modified/GM); teknologi DNA; kloning gen atau cloning molekuler merupakan istilah yang meliputi sejumlah teknik/metode/prosedur yang digunakan untuk mengidentifikasi, meniru, memodifikasi dan mentransfer materi genetik dari sel, jaringan atau mahluk hidup lengkap dari satu mahluk hidup ke mahluk hidup lainnya (Izquierdo, 2001; Karp, 2002; Sudjadi, 2008; Artanti et al., 2010). Teknologi yang paling banyak digunakan adalah rekombinasi DNA (DNA recombinant), suatu metode yang digunakan untuk memanipulasi langsung DNA yang berorientasi pada ekspresi gen tertentu. Teknik ini melibatkan kemampuan untuk mengisolasi, memotong dan memindahkan potongan DNA tertentu sesuai dengan gen-gen yang menjadi target (Klug dan Cummings, 2002; Singh et al., 2006; Artanti et al., 2010). Saat ini memanipulasi DNA dalam berbagai cara dan memindahkannya dari satu mahluk hidup ke mahluk hidup lain dapat diprogramkan melalui teknik rekombinasi DNA untuk memproduksi berbagai zat seperti enzim, antibodi monoklonal, nutrisi, hormon, dan berbagai produk farmasi termasuk obat dan vaksin dalam jumlah besar (Brown, 1996; Campbell, 1996;
Radji, 2009).

Suwanto (2006) menjelaskan secara detail bahwa rekayasa genetika merupakan suatu teknik alternatif untuk melakukan modifikasi bahan genetik pada suatu mahluk hidup. Perbedaan utamanya dengan teknik pemuliaan yang lain adalah dalam hal tingkat ketepatan dan kecepatan hasil mutasinya. Mutan yang diperoleh melalui teknologi DNA merupakan hasil mutagenesis langsung pada sasarannya (site directed mutagenesis), sedangkan mutasi buatan secara fisika atau kimia bersifat acak (random mutagenesis) seringkali menghasilkan mutan yang bersifat pleiotrof (mutasi di luar gen sasaran). Selain itu, teknologi DNA juga memungkinkan penambahan atau penyisipan gen dari kelompok mahluk hidup yang secara filogenetik sangat jauh hubungan kekerabatannya atau secara seksual tidak kompatibel. Berdasarkan penjelasan tersebut, maka pengertian GMO menurut Suwanto (2006) adalah mahluk hidup hasil modifikasi bahan genetik melalui teknologi DNA, sedangkan yang melalui persilangan, mutasi kimia atau fisika tidak dikategorikan sebagai GMO.

\section{Kontroversi Produk GMO}

Pelepasan GMO ke lingkungan telah menjadi kontroversial di seluruh dunia (Amin dan Jahi, 2004; Singh et al., 2006). Kontroversi tersebut terkait dengan kemungkinan resiko terhadap berbagai aspek kehidupan masyarakat seperti: kesehatan, lingkungan, agama, budaya, etika, psikologi, dan lain-lain. Suatu teknologi dapat memberi manfaat yang besar bagi kesejahteraan masyarakat, akan tetapi tidaklah mutlak tanpa resiko, begitu juga dengan rekayasa genetika. Beberapa contoh dampak positif rekayasa genetika sebagai berikut: meningkatnya derajat kesehatan manusia dengan diproduksinya berbagai hormone manusia seperti insulin 
dan hormone pertumbuhan; tersedianya bahan makanan yang lebih melimpah; tersedianya sumber energi terbaharui; proses industri yang lebih murah; dan berkurangnya polusi. Menurut Epstein (2001), sebagian besar efek dari rekayasa genetika yang mampu mengubah sifat fisik mahluk hidup belum diketahui. Salah satu masalah utama dalam rekayasa genetika adalah apakah gen yang disisipkan dalam suatu mahluk hidup akan diwariskan atau tidak diwariskan dari satu generasi ke generasi berikutnya ?. Meskipun dengan penggunaan teknologi transgenik diakui memiliki kemampuan untuk mengekspresikan gen asing dan membuka opsi untuk memproduksi sejumlah besar produk industri seperti industri farmasi komersial, tetap saja masih menyisakan kekhawatiran (Singh et al., 2006).

Kekhawatiran munculnya dampak negatif dari penggunaan GMO di Indonesia sangat beralasan karena Indonesia telah mengimpor berbagai komoditas yang diduga sebagai hasil dari rekayasa genetika maupun yang tercemar dengan GMO yang berasal dari negara-negara yang telah menggunakan teknologi rekayasa genetika, mulai dari tanaman, bahan pangan dan pakan, obat-obatan, hormon, bunga, perkayuan, hasil perkebunan, hasil peternakan dan sebagainya diduga mengandung atau tercemar GMO (Agorsiloku, 2006). Diakui bahwa GMO telah menguasai pasar dunia, karena telah memberikan manfaat bagi kehidupan manusia meskipun juga disadari memberi dampak negatif yang tidak bisa dianggap sepele, tetapi sangat disayangkan hingga saat ini rasa-rasanya belum pernah dilaporkan adanya dampak negatif dari penggunaan GMO. Jangankan mendeteksi dampak negatif penggunaan GMO, mendeteksi apakah komoditas yang diimpor mengandung GMO saja belum pernah dilakukan di Indonesia. Biasanya kalau sudah ada kejadian baru-baru ini seperti apel impor dari Amerika Serikat memunculkan sejumlah bakteri yang diduga sangat berbahaya bagi kesehatan konsumen, baru dilakukan pengujian laboratorium.

Sutardi (2007) mengatakan percepatan dan penerapan inovasi teknologi rekayasa genetika dibidang pertanian seperti Genetically Modified Organism (GMO), Living Modified Organism (LMO), Genetically Modified Crops (GMC) dan Genetically Engineered Crops (GEC) telah mengundang pro dan kontra di tengahtengah kehidupan masyarakat dunia, baik yang terjadi di negara dimana produk itu dikembangkan maupun di negara-negara pengguna. Selanjutnya dikatakan bahwa dengan penerapan teknologi rekayasa genetika di bidang pertanian akan berdampak buruk bagi kesehatan masyarakat. Faktor dampak yang ditimbulkan GMO baik positif dan negatif inilah yang menyebabkan kontrorversial di tengah-tengah masyarakat. Berikut ini diuraikan kontroversi masyarakat terhadap penerimaan dan penggunaan produk GMO baik dalam bidang pertanian, lingkungan, kesehatan, agama, budaya, dan etika.

\section{Kontroversi GMO di bidang pertanian dan lingkungan}

Pada dasarnya tidak selamanya pemindahan gen dapat dilakukan dengan merekayasa gen-gen tertentu pada mahluk hidup tertentu melalui teknik DNA rekombinan untuk memproduksi berbagai zat yang diinginkan. Menurut Phillips (1994), materi genetik baru mungkin tidak berhasil dipindahkan ke sel target, atau mungkin dipindahkan ke sebuah tempat yang salah pada rantai DNA dari mahluk hidup sasaran, atau gen baru mungkin secara tidak sengaja mengaktifkan gen dekatnya yang biasanya tidak aktif, atau mungkin mengubah atau menekan fungsi gen yang berbeda. Fenomena ini dapat 
menyebabkan mutasi tak terduga sehingga membuat tanaman yang dihasilkan beracun, subur, atau tidak sesuai dengan yang diinginkan. Selain itu, tanaman rekayasa genetika berpotensi merusak keseimbangan lingkungan di sekitarnya. Hama dan penyakit tanaman akan lari ke ladang-ladang konvensional sehingga mau tidak mau petani tersebut harus beralih menjadi pengguna tanaman transgenik yang harganya relatif mahal. Pemerhati lingkungan khawatir bahwa tanaman transgenik akan menimbulkan resiko lingkungan ketika tanaman tersebut secara luas dibudidayakan (Kaiser, 1996).

Pada umumnya pola tanam produk pertanian di Indonesia dilakukan pada areal kecil yang dikelilingi oleh berbagai gulma (tumbuhan pengganggu), dan dengan adanya sifat penyerbukan silang (crosspolination) secara alamiah dari tanaman GMO, maka dikhawatirkan akan bermunculan gulma baru yang lebih resisten terhadap herbisida misalnya. Permasalahan lain yang diduga akan muncul adalah terbunuhnya mahluk hidup lainnya seperti larva kupu-kupu yang selanjutnya dikhawatirkan akan punahnya kupu-kupu sebagai akibat dari sisa tanaman transgenik bersifat toksis. Dalam jangka panjang tanaman transgenik ini akan merubah struktur dan tekstur tanah yang akan berdampak pada kuantitas dan kualitas produksi tanaman (Agorsiloku, 2006).

Jauh sebelumnya, Hileman (1999) mengatakan bahwa tanaman transgenik memiliki herbisida dan serangga perlawanan yag sewaktu waktu bisa melakukan penyerbukan silang dengan spesies liar, dan dapat memproduksi zat tertentu yang bisa memberantas gulma terutama pada areal pertanian kecil yang dikelilingi oleh tanaman liar. Dampak positif tanaman yang mampu memproduksi zat yang dapat memberantas gulma adalah mengurangi biaya karena tidak perlu membeli herbisida yang harganya relatif mahal bagi petani. Di sisi lain perlu diingat bahwa peristiwa penyerbukan silang diduga dapat menyebabkan transfer gen yang tidak disengaja, hal ini dapat memiliki konsekuensi yang belum diketahui meskipun sulit untuk dibukktikan. Dalam fenomena ini, gulma tersebut dapat menjadi tanaman invasif dengan potensi mampu menurunkan hasil panen dan mengganggu ekosistem alami. Tanaman transgenik yang bisa menjadi gulma tentu membutuhkan program pengendalian kimia dengan biaya mahal dan membahayakan lingkungan (Rissler dan Mellon, 1993).

Kemunngkinan munculnya virus baru dan racun pada tanaman transgenik merupakan bagian dari strategi untuk meningkatkan ketahanan tanaman seperti yang dilakukan di India (Phillips, 1994; Kamle et al., 2011). Di sisi lain, komersialisasi tanaman transgenik dari beberapa varietas telah mendapatkan dukungan dunia internasional meskipun diduga akan menimbulkan ancaman baru terutama terhadap kepunahan keragaman genetik khususnya di negara-negara berkembang (Phillips, 1994; Koch, 1998; Pedreschi et al., 2010; Cantley, 2012). Di tengah-tengah ramainya kontroversial masyarakat di berbagai negara di dunia terhadap produk GMO, lain halnya dengan sikap masyarakat Eropa khususnya telah menyetujui pengembangan dan penggunaan GMO atas persetujuan kementerian lingkungan meskipun masih menimbulkan konflik, baik antar departemen, antar sektor, antar negara dan antar lembaga internasional (Cantley, 2012).

\section{Kontroversi GMO di bidang kesehatan}

Derajat kesehatan masyarakat dari waktu ke waktu terus meningkat dengan diproduksinya berbagai hormone manusia 
seperti insulin dan hormone pertumbuhan; tersedianya bahan makanan yang lebih melimpah; tersedianya sumber energi terbaharui; proses industri yang lebih murah; dan berkurangnya polusi. Produksi obat GMO seperti insulin, antibodi monoklonal, anti alergi, anti kanker dan masih banyak lagi obat-obatan lainnya untuk menyembuhkan berbagi penyakit telah dirasakan manfaatnya oleh masyarakat seperti yang dilaporkan oleh Singh et al. (2006) bahwa kemampuan untuk mengekspresikan gen asing menggunakan teknologi rekayasa genetika telah membuka opsi untuk memproduksi sejumlah besar produk makanan dan obatobatan/farmasi komersial penting untuk meningkatkan derajat kesehatan masyarakat, meskipun banyak kekhawatiran tentang dampak negatif yang muncul.

Baru-baru ini Schagen et al. (2014) melaporkan bahwa obat manusia pertama yang dimodifikasi secara genetik telah diizinkan untuk digunakan di pasar Eropa dengan mencantumkan deskripsi penggunaannya. Young dan Lewis (1995) mengatakan bahwa sedikit sekali informasi yang terkait dengan efek dari perubahan komposisi gizi pangan GMO baik yang berasal dari tanaman dan hewan seperti pada level interaksi hara, interaksi nutrisi, interaksi gen, bioavailabilitas/absorpsi nutrisi, potensi gizi, metabolisme nutrisi, dan ekspresi gen tentang situasi di mana nutrisi diubah. Berdasarkan informasi ini, diduga belum ada satu penelitian yang menjamin pangan rekayasa genetika 100 persen aman untuk di konsumsi. Pangan hasil rekayasa genetika diduga menjadi penyebab berbagai penyakit dengan asumsi bahwa gen asing mungkin mengubah nilai gizi makanan dengan cara yang tak terduga baik yang bisa mengurangi atau meningkatkan beberapa gizi dan nutrisi lain. Faktor yang perlu diperhatikan dari minimnya informasi tersebut adalah penggunaan produk makanan dari GMO harus berhati-hati (Small et al., 2005).

Kekhawatiran lainnya adalah resistensi antibiotik ke dalam tanaman yang banyak dikonsumsi dimungkinkan memiliki dampak negatif yang tidak diinginkan bagi kesehatan manusia dan hewan yang mengkonsumsi tanaman tersebut (Phillips, 1994). Di dalam tubuh mahluk hidup transgenik, memungkinkan gen penanda resisten antibiotik dimasukkan ke tanaman tertentu dan dapat ditransfer ke mikroba penyebab penyakit dalam usus manusia atau hewan yang mengkonsumsi makanan produk rekayasa genetika. Fenomena ini dapat mengakibatkan mikroba resisten terhadap antibiotik dalam populasi mahluk hidup, dan selanjutnya berkontribusi terhadap masalah kesehatan manusia yang resisten antibiotik (Bettelheim, 1999; Hileman, 1999).

Selain itu, banyak makanan GMO menggunakan mikroorganisme sebagai donor potensial menimbulkan alergi yang tidak diketahui atau belum teruji. Gen dari sumber-sumber non-makanan dan kombinasi gen baru bisa memicu reaksi alergi pada beberapa orang yang mengkonsumsinya atau memperburuk yang sudah ada. Nordlee et al. (1996) melaporkan bahwa kacang Brazil sebagai salah satu produk GMO ditarik dari peredaran karena menyebabkan alergi pada konsumen. Reaksi alergi tersebut diduga disebabkan oleh modifikasi gen tertentu.

Gerakan penolakan terhadap pangan GMO sampai saat ini terus terjadi di berbagai negara di dunia. Satu contoh kampanye makanan alami dari sebuah kelompok advokasi makanan yang berbasis di Washington DC telah mengkampanyekan resiko pangan dari GMO seperti kehilangan nutrisi, kemunculan racun baru, alergen dan efek 
samping potensial lainnya (Billings, 1999; Coleman, 1996; Robinson, 2013). Indonesia sebagai salah satu negara yang banyak memanfaatkan GMO harus lebih berhati-hati, sebab hingga saat ini diduga belum pernah dilaporkan adanya dampak negatif dari penggunaan GMO tersebut, apalagi mendeteksi apakah komoditas yang diimpor mengandung GMO atau tidak. Ke depan, prinsip kehati-hatian penggunaan GMO impor harus dikedepankan, oleh karena itu peran pemerintah dan ilmuwan sangat ditunggu.

\section{Kontroversi GMO di bidang agama, budaya, dan etika}

Produk GMO khususnya pangan memiliki beberapa manfaat bagi manusia, namun masih saja menimbulkan berbagai kontroversi termasuk kontroversi agama, budaya, etika, sosial, hukum, dan psikologi (Anwar, 2010; Pramashinta et al., 2014). Produk pangan GMO memang menjanjikan efisiensi yang lebih baik daripada produk konvensional, karena kebijakan produk GMO di seluruh dunia harus mengakomodir dampak terhadap banyak hal termasuk diantaranya kesehatan, lingkungan, serta aspek normatif dari sisi adat/budaya, etika dan agama. Persoalan agama, budaya dan etika merupakan masalah yang sangat sensitif khusunya bagi masyarakat Indonesia yang memiliki budaya timur.

Kelompok masyarakat muslim di Indonesia sebagai kelompok mayoritas memiliki ketentuan yang mengharuskan pangan yang dikonsumsi adalah yang halal dan baik (halalan toyyiban), sehingga menjadi sangat penting pencantuman keterangan/label tentang kandungan suatu produk pangan dan obat-obatan hasil GMO meskipun tidak mudah untuk melacak kandungan GMO tersebut, untuk itu diperlukan suatu mekanisme yang jelas untuk melakukan pelacakan dan pemantauan kandungan GMO yang beredar luas. Singh et al. (2006) mengatakan bahwa mekanisme pelacakan, penilaian resiko dan pemantauan yang efektif merupakan prasyarat dasar kerangka hukum untuk merespon resiko dan kehatihatian yang akan memunculkan resiko baru.

Aspek yang juga sangat penting adalah pencantuman sertifikat halal yang dikeluarkan oleh Lembaga Pengkajian dan Pengawasan Obat dan Makanan Majelis Ulama Indonesia (LP POM MUI) sehingga kekhawatiran masyarakat yang beragama Islam dalam mengkonsumsi produk GMO tidak berkembang dan meresahkan. Kessler et al. (1992) melaporkan bahwa tanaman GMO memerlukan label jika menimbulkan beberapa ancaman yang teridentifikasi seperti reaksi alergi atau menyebabkan perubahan dramatis dalam kandungan gizi. Namun, beberapa orang optimis bahwa teknologi yang dapat dengan mudah membedakan pangan GMO dari yang non GMO akan segera dikembangkan, sehingga pelabelan sangat diperlukan dalam upaya meyakinkan bahwa produk GMO aman untuk dikonsumsi oleh masyarakat (Hoef et al., 1998; Burachik, 2010).

Sesungguhnya kekhawatiran terkait dengan agama, budaya, dan etika telah disuarakan oleh berbagai kelompok masyarakat sebagai alasan untuk menentang produk GMO khususnya dalam bidang pangan, sementara sejumlah orang keberatan dengan makanan tersebut untuk alasan pribadi, etika, budaya, estetika, dan pelanggaran pada pilihan konsumen serta ketidakmampuan untuk membedakan makanan dari GMO dan non GMO (Robinson, 1997; Thompson, 1997; Artanti et al., 2010). Sebagai contoh, orang-orang non muslim dan muslim mungkin bermusuhan dengan produk tanaman GMO khususnya biji-bijian yang mengandung gen babi, dan biasanya mereka bersikeras terhadap makanan halal yang 
kemurniannya dapat didokumentasikan. Demikian halnya dengan kelompok vegetarian mungkin sama khawatirnya terhadap sayuran dan buah-buahan yang mengandung gen hewan, dan beberapa orang takut makan makanan nabati dari GMO yang mengandung gen manusia (Crist, 1996).

Sehubungan dengan penolakan produk GMO sekarang ini yang cenderung meningkat, Pemerintah Amerika Serikat telah mengantisipasi kehawatiran tersebut dengam membuat peraturan perundangan yang memberikan keamanan pangan GMO yang terjamin (Robinson, 2013). Fenomena yang hampir sama juga terjadi di negaranegara yang tergabung dalam Uni Eropa (UE) seperti yang dilaporkan oleh Schagen et al. (2014) bahwa obat manusia pertama yang dimodifikasi secara genetika telah diizinkan untuk digunakan di pasar Eropa tanpa mendapatkan izin khusus, tetapi obat GMO tersebut harus berisi deskripsi penggunaannya sebagaimana yang diatur dalam undang-undang lingkungan nasional masing-masing negara anggota Uni Eropa.

Indonesia sebagai negara berkembang yang banyak menggunakan produk GMO khususnya pangan dan obat-obatan telah mengantisipasinya dengan membuat perangkat hukum yang dapat melindungi konsumen dari resiko yang tidak diinginkan. Abbas (1999) melaporkan bahwa pemanfaatan produk rekayasa genetika di Indonesia harus mengacu pada beberapa peraturan perundang-undangan, antara lain: (1) UU No. 7/1996 tentang Pangan; (2) UU No. 21/2004 tentang Protokol Cartagena; (3) PP No. 69/1999 tentang Label dan Iklan Pangan; (4) PP No. 28/2004 tentang Keamanan, Mutu dan Gizi Pangan; (5) PP No. 21/2005 tentang Keamanan Hayati Produk Rekayasa Genetik; (6) SKB 4 Menteri Th. 1999; (7) Peraturan Kepala Badan POM RI Nomor : HK.00.05.23.3541 Tahun 2008 tentang
Pedoman Pengkajian Keamanan Pangan Produk Rekayasa Genetik; dan lain-lain.

Sesungguhnya perangkat hukum yang mengatur peredaran dan penggunaan GMO sudah banyak dan memadai, hanya saja implementasinya yang belum berjalan maksimal. Satu contoh yang dilaporkan oleh Abbas (2009) adalah pencantuman keterangan halal pada kemasan atau label dari suatu produk pangan yang memang halal, merupakan keharusan karena adanya kata wajib dalam redaksi Pasal 30 ayat (1) junto ayat (2) UU Pangan, hal ini berarti bahwa ketentuan tersebut bersifat imperatif. Fenomena lapangan yang ada justru sebaliknya banyak produk pangan yang beredar mencantuman kata halal pada kemasannya, padahal sesungguhnya belum pernah meminta sertifikat halal pada LP POM MUI, karena memang tidak adanya keharusan bagi produsen pangan untuk mencantumkan nomor sertifikat halalnya, sehingga hal ini menyulitkan BPOM untuk melakukan pengawasan.

Malaysia sebagai salah satu negara tetangga bergerak cepat dalam meredam kekhawatiran masyarakat muslim terhadap semua produk GMO seperti yang dilaporkan oleh Amin et al. (2010) bahwa dibutuhkan otoritas agama Islam dan para ulama untuk mengeluarkan panduan yang jelas tentang status halal dari berbagai jenis produk GMO dalam rangka membimbing masyarakat muslim. Demikian juga Badan Pengawas Pangan dan obat-obatan yang dibentuk pemerintah berdasarkan undangundang yang ada harus bertanggungjawab terhadap penggunaan GMO, memberikan panduan etika yang jelas dan semua informasi terkait GMO harus disebarluaskan kepada publik. Perangkat hukum yang digunakan Pemerintah Malaysia adalah Undang-Undang Keamanan Hayati yang telah dikukuhkan oleh parlemen pada tahun 2007, dan telah berlaku sejak 2009. Undang-undang 
tersebut mengatur tentang impor, ekspor dan penggunaan GMO dengan tujuan melindungi manusia, tanaman dan kesehatan hewan, lingkungan dan keanekaragaman hayati.

Di dalam implementasi UndangUndang Keamanan Hayati tersebut, produk GMO yang bertentangan dengan undangundang tersebut dipastikan mendapatkan penolakan. Amin et al. (2010) juga melaporkan hasil penelitiannya bahwa masyarakat muslim Malaysia menolak transfer gen hewan untuk tanaman, tetapi mereka tidak secara tegas mengizinkan memodifikasi makhluk hidup untuk kepentingan mereka serta rekayasa genetika dapat mengancam lingkungan dan mahluk hidup yang ada. Jika semua perangkat hukum yang mengatur penggunaan produk-produk GMO di Indonesia, maka kekhawatiran dan kontroversi yang terjadi di masyarakat baik dilihat dari kaca mata agama, budaya, etika, psikologi, dan aspek lainnya tidak akan muncul atau setidak-tidaknya dapat dikurangi.

\section{SIMPULAN}

Kesimpulan dari pembahasan paper ini adalah: (1) rekayasa genetika memiliki potensi yang sangat besar terutama dalam mengatasi kekurangan pangan penduduk dunia dan membantu melestarikan lingkungan meskipun masih memunculkan kontroversial yang melibatkan konsumen, petani, perusahaan GMO, pemerintah sebagai regulator, organisasi nonpemerintah, dan ilmuwan; (2) masyarakat harus mendapatkan informasi lengkap tentang resiko dan manfaat dari produkproduk GMO, dan semua pangan dari produk GMO diberi label dengan detail termasuk kandungan produk dan gen yang dimasukkan; (3) penelitian rekayasa genetika yang mendalam dan independen tetap dilanjutkan untuk digunakan sebagai bahan pertimbangan rasional dalam rangka membuat peraturan perundangan yang secara ilmiah dapat dipertanggungjawabkan, sehingga peraturan tersebut tidak hanya melindungi konsumen dari bahaya yang menimpanya, tetapi juga memungkinkan konsumen untuk memanfaatkan produk GMO dan teknologi pendukungnya secara maksimal; dan (4) peraturan perundang-undangan yang terkait dengan pengembangan dan penggunaan GMO harus dijalankan dengan sebaik-baiknya oleh semua pihak.

\section{DAFTAR PUSTAKA}

Abbas, N. 2009. Perkembangan Teknologi di Bidang Produksi Pangan dan Obatobatan serta Hak-hak Konsumen, Jurnal hukum, 3 (16): 423 - 438.

Agorsiloku. 2006. Dampak Penggunaan Hasil Rekayasa Genetika. https://agorsiloku.wordpress.com/2006 /11/13/. Diakses tanggal 10-1-2015.

Alberts, B., A. Johnson, J. Lewis, M. Raff, K. Roberts, P. Walter. 2008. Molecular Biology of The Cell. $5^{\text {th }} E d$. Garland Science, USA. Pp 1268.

Amin, L dan J.M. Jahi. 2004. Ethical Aspects of Genetically Modified Organisms Release into the Environment. Malaysian Journal of Environmental Management, (5): 99 111.

Amin, L., A. A. Azlan, M. H. Gausmian, J. Ahmad., A. L. Samian, M. S. Haron, dan N. M. Sidek. 2010. Ethical perception of modern biotechnology with special focus on genetically modified food among Muslims in Malaysia. AsPac J. Mol. Biol. Biotechnol., 18 (3) : 359-367.

Anwar, A. 2010. Penerapan Bioteknologi Rekayasa Genetik dibidang Medis 
Ditinjau dari Perspektif Filsafat Pancasila, Ham dan Hukum Kesehatan di Indonesia, Jurnal Sasi, 17 (4): 3951.

Artanti, G.D., Hardinsyah, D. K. S. Swastika, dan Retnaningsih. 2010. Analisis faktor-faktor yang mempengaruhi penerimaan petani terhadap produk rekayasa genetika. Jurnal Gizi dan Pangan, 5 (2): 113 120.

Asaye, M., H. Biyazen, dan M. Girma. 2014. Genetic engineering in animal production: Applications and prospects. Biochemistry and Biotechnology Research, 2(2): 12-22.

Azadi, H dan H. Peter. 2010. Genetically modified and organic crops in developing countries: A review of options for food security. Biotechnology Advances, 28: 160-168.

Badan Pusat Statistik (BPS). 2013. Sepuluh Bahan Pangan Yang Terus Diimpor. http://www.asiabusinessinfo.com/baha n-pangan-yang-terus-di-impor/. Diakses 27-11-2014.

Bettelheim, A. 1999. Drug resistant bacteria: Can scientists find a way to control 'superbugs'? CQ Researcher, 9(21): 473-96.

Billings, P.R. 1999. Modified foods are like drugs. The Boston Globe, 28th August 1999.

Brown, K. S. 1996. Prescription: one plant please. Bioscience, 46(2):82.

Burachik, M. 2010. Experience from use of GMOs in Argentinian agriculture, economy and environment. $\underline{N}$ Biotechnol., 27 (5): 588-592.

Campbell, P.O.Q. 1996. Super foods: agricultural products and genetic engineering. Biology Digest., 1 (23):
$10-17$.

Cantley, M. 2012. European Attitudes on the Regulation of Modern Biotechnology and their consequences, GM Crops and Food: Biotechnology in Agriculture and the Food Chain, 3(1): 40-47.

Coleman, A. 1996. Production of proteins in the milk of transgenic livestock: problems, solutions and success. Am $\mathrm{J}$ Clin Nutr., 63: 5639-5645.

Crist, W.E. 1996. Waiter, there's a flounder in my fruit. (Bio-engineered fruits and vegetables with animal genetic materials are not so labeled). Vegetarian Times, 231: 22.

Curran, G. J., Y.J. Koszarycz. 2004. Genetic Engineering: Creating an Ethical Framework. Australian eJournal of Theology 2: 1-13.

Dano, E. C. 2007. Potential SocioEconomic, Cultural and Ethical Impacts of GMOs: Prospects for Socio-Economic Impact Assessment. TWN (ISBN: 978-983-2729-23-5), $3^{\text {th }}$ World Network, Penang Malaysia. Pp 32.

Dresbach, S.H., H. Flax, A. Sokolowski, dan J. Allred. 2001. The Impact of Genetically Modified Organisms on Human Health. Ohio State University Extension Fact Sheet HYG-5058-01. http://ohioline.osu.edu/hygfact $/ 5000 / 5058 . h t m l$.

Epstein, R. 2001. Redesigning the World Ethical Questions About Genetic Engineering. Vajra Bodhi Sea: A MonthlyJournal of Orthodox Buddhism, 32(76): 34-39. 2001. $<$ http://online.sfsu.edu/\%7Erone/GEes says/

Hardinsyah. 2000. Potensi Kekuatan dan Kelemahan Produk Pangan Hasil 
Rekayasa Genetika. Makalah pada Seminar Pangan Rekayasa Genetika. Kolaborasi, Bogor.

Hileman, B. 1999. UK moratorium on biotech crops. Chemical \& Eng News May, Pp 7.

Hoef, A. M., E.J. Kok, E. Bowo, H.A. Kuiper, J. Keijer. 1998. Development and application of a selective detection method for genetically modified soy and soy derived products. Food Add Contamin, 15(7): 767-74.

Izquierdo, R. M. 2001. Genetic Engineering. $2^{\text {nd }}$ Ed. Pyramid, Madrid, Pp 344.

Kaiser, J. 1996. Pests Overwhelm Bt Cotton Crop. Science, 273: 423.

Kamle, S., A. Kumar, R.K. Bhatnagar. 2011. Development of multiplex and construct specific PCR assay for detection of cry $2 \mathrm{Ab}$ transgene in genetically modified crops and product. GM Crops, 2(1): 74-81.

Karp, G. 2002. Cell and Molecular Biology: concepts and Experiments, $3^{\text {rd }} E d$. John Wiley and Sons, New York, Pp 785.

Kessler, D.A., M.R. Taylor, J.H. Maryanski, E.L. Flamm, L.S. Kahl. 1992. The safety of foods developed by biotechnology. Science, 256:1747.

Klug, W. S dan M. R. Cummings. 2002. Concepts of Genetics. $7^{\text {th }}$ Ed. ISBN 0130929980. Prentice Hall, New Jersey, Pp 800.

Koch, K. 1998. Food safety battle: organic vs. biotech. Congressional Quarterly Researcher, 9(33): 761-84.

Lotter, D. 2008. The Genetic Engineering of Food and the Failure of Science Part 1: The Development of a Flawed Enterprise. Int. Jrnl. of Soc. of Agr. \&
Food, 16(1): 31-49.

Marinho, C.D., F.J.O. Martins, A.T. Amaral Júnior, L.S.A. Gonçalves, S.C.S. Amaral, dan M. P. de Mello. 2012. Use of transgenic seeds in Brazilian agriculture and concentration of agricultural production to large agribusinesses. Genet. Mol. Res., 11 (3): 1861-1880.

Montaldo, 2006. Genetic engineering applications in animal breeding. Electronic Journal of Biotechnology ISSN: 0717-3458 Vol.9 No.2, Issue of April 15, 2006.Redesigning.htm>

Nordlee, J. A, S.L. Taylor, J.A. Townsend, L.A. Thomas, R.K. Bush. 1996. dentification of Brazil nut allergen in transgenic soybeans. $N$ Engl J Med., 334: 668-92.

Nursamsi, 2008. Peluang dan Tantangan Produk Pertanian di Era Global. Pengukuhan Prof Nursamsi di Universitas Gajah Mada. http://www.ugm.ac.id/id/. Diakses 17 1-2015.

Pedreschi, R., M. Hertog, K.S. Lilley, B. Nicolaï. 2010. Proteomics for the food industry: opportunities and challenges. Crit Rev Food Sci Nutr., 50(7): 680692.

Phillips, S.C. 1994. Genetically engineered foods: do they pose health and environmental hazards?. CQ Researcher, 4(29): 673-96.

Pramashinta, A., L. Riska, Hadiyanto. 2014. Bioteknologi Pangan: Sejarah, Manfaat dan Potensi Resiko. Review. Jurnal Aplikasi Teknologi Pangan, 3 (1): 1-6.

Radji, M. 2009. Vaksin DNA:Vaksin Generasi Keempat. Majalah Ilmu Kefarmasian, 6(1): 28 - 37. 
Rissler, J dan M. Mellon. 1993. Perils amid the promise: ecological risks of transgenic crops in a global market. Union of Concerned Scientists, Washington D.C.

Robinson, R. E. 2013. A bumpy road ahead for producers, buyers and sellers of Genetically Modified Organisms. The newsletter of the Illinois State Bar Association's Section on Agricultural Law, 23 (1).

Robinson, C. 1997. Genetically modified foods and consumer choice. Trends in Food Science and Technol., 8:84-8.

Schagen, F.H., R. C. Hoeben, G. A. Hospers. 2014. Off-label prescription of genetically modified organism medicines in europe: emerging conflicts of interest?. Hum Gene Ther., 25(10): 893-896.

Singh, O.V., S. Ghai, D. Paul, R. K. Jain. 2006. Genetically modified crops: success, safety assessment, and public concern. Appl Microbiol Biotechnol., 71(5): 598-607.

Small, B. 2004. Emotion and evolution in science and ethics. Reflections on the use of human genes in other organisms: Ethical, spiritual, and cultural dimensions. Wellington: Toi teTaiao-the Bioethics Council..

Small, B., T. G. Parminter, M. W. Fisher.
2005. Understanding public responses to genetic engineering through exploring intentions to purchase a hypothetical functional food derived from genetically modified dairy cattle. New Zealand Journal of Agricultural Research, 48: 391-400.

Sudjadi, 2008. Bioteknologi Kesehatan, Kanisius, Yogyakarta. Pp 279.

Sutardi, 2007. Produk Pertanian Transgenik Belum Diyakini Aman. Pidato Ilmiah pada Pengukuhan Guru Besar Prof Sutard di Universitas Gajah Mada. http://www.ugm.ac.id/id/. Diakses tgl 17-1-2015.

Suwanto, A. 2006. Genetically Modified Organisms (GMOs): Keragaman Genetik dan Preferensi Manusia. Institut Pertanian Bogor.

Thompson, P. B. 1997. Food biotechnology's challenge to cultural integrity and individual consent. Hastings Center Report, 27(4): 34-8.

Uzogara, S. G. 2000. The impact of genetic modification of human foods in the $21^{\text {st }}$ century: A review. Biotechnology Advances, 18:179-206.

Young, A. L dan C.G. Lewis. Biotechnology and potential nutritional implications for children. Pediatr Clin North Am., 42(4): 917-30. 